Oral Tradition, 2/2-3 (1987): 645-66

\title{
The Structure and Changing Functions of Oral Traditions
}

\author{
Beatriz Mariscal de Rhett \\ Not graven on tablets was this law, nor sealed \\ Within papyrus rolls, but in plain speech \\ Delivered to thee from a dauntless tongue. \\ (Aeschylus, The Suppliants)
}

The transmission of knowledge by means of oral literary forms, so strongly attacked by Plato in the fourth century B.C., has not disappeared completely. ${ }^{1}$ Throughout the many centuries of supremacy of the written word over non-written communication, many non-literate communities have retained literary traditions that rely on being memorized and orally transmitted by members of that community. Oral traditions that have been able to adapt themselves to the changes in their environment have been able to survive to our day in coexistence with forms of literate origin, although mostly relegated to marginal social groups.

One of the oral literary genres that still retains great vitality is the Hispanic romancero. Field research begun at the end of the nineteenth century in several regions of the Iberian Peninsula and, since the turn of the century, expanded to other Spanish and Portuguese peninsular and insular areas, to Africa and the Near East where Sephardic communities settled, and to some Latin American countries, proved that the traditional romancero was alive in practically all of the Spanish- and Portuguesespeaking world.

During the past few years, interest in this type of literature has increased considerably. Field research in Latin America and among Sephardim and Portuguese residing in Canada and the United States has complemented the somewhat sketchy picture we had of the romancero tradition on this continent. Concerning the Peninsular tradition, individual researchers as well as a number of 
research groups directed by the Instituto Menéndez Pidal of the Universidad Complutense of Madrid and sponsored by United States, Spanish, and Portuguese institutions have carried out extensive field trips in Spain and Portugal to collect romances. These field trips have been very successful; several thousand romance texts, some of them quite rare, have been collected from oral tradition during the last decade. ${ }^{2}$

Romances, like all other oral traditions that live in the collective memory of the people, must fulfill some social function within the communities that retain them in order to survive the overpowering intrusion of the more prestigious literary forms, and they must be structured in such a way that they can be memorized not only by especially gifted people, but by practically anyone in the community. ${ }^{3}$ As the environment changes, romances adapt structurally and functionally to those changes in order to remain in the tradition. My observations will center on these two aspects of the adaptation of oral traditions to their dynamic environments.

Since the sixteenth and seventeenth centuries, when the romancero was most popular both at court and among the common people, the occasions for the singing of romances have become fewer as the genre has been relegated mostly to rural communities. What for centuries were "natural" occasions for the singing or reciting of romances have been practically eliminated within the past four or five decades. Traditional romances are still being sung during some communal tasks, such as the harvesting of olives in the south of Spain, during festive occasions mostly of a family nature (christenings or weddings), or during summer afternoons when small groups of women get together to knit or sew outside their homes (an occasion that has proved very fruitful In our collecting work). However, other occasions such as the filandones, where women of different generations could sing romances as they got together to spin wool, are no longer common, and the noise of tractors has effectively eliminated the singing of romances that used to accompany different agricultural chores. The collective nature of the creative process of this type of literature remains, nevertheless, unchanged.

In spite of the more limited occurrence of romance singing, romance narratives continue to function as a means of transmitting social values or commenting on social problems. Whether they talk about "el príncipe don Juan" (Prince John, son of the Catholic 
Kings) or "el novio de Ricardina" (Ricardina's boyfriend), two alternative characterizations of the protagonist of La muerte del príncipe don Juan, romances are understood by their interpreters as dealing with what happens in life, "cosas de la vida," as was very clearly stated by a romance singer. When the narratives, which may have originated several centuries ago, or even in another culture, are adopted by a community, they become a part of its particular culture as a result of the capacity of this type of structure to adapt to the world in which it lives.

Unlike other traditions, the romancero is, in general, not transmitted by special singers, although the individual who has a good voice or a good memory will most likely retain a greater number of romance themes. Any member of the community can participate in the transmission/creation of this traditional art. Both young and old have memorized and sung romances for hundreds of years without any differentiation being made between the "producer" or performer of the text and the "consumer" or receiver, since the latter will in turn become the producer.

When in response to our inquiries someone sings or recites romances, either because they concede spontaneously that they know romances or because others who have heard them prompt them to do so, there is always some intervention on the part of others present, even if they claimed they did not know any romances Non-singing bystanders not only help the person singing or reciting to remember certain lines or passages they might have forgotten, they also tend to reject anything that does not correspond to what they learned or think is right. The singer will sometimes modify her or his version to conform to what the other members of the community perceive to be either correct or superior. As a consumer of romances, anyone can be as much a part of the productive process as the person in charge of the performance, even though not every contribution has aesthetic value.

The non-specialized character of romance singers assures the possibility of a wide participation by the members of the community in their "appropriation" of the text. Whatever change occurs within the narrative structure is consensual and the result of the natural process of adaptation of the text to its dynamic environment and to changing communication needs of the community. In contrast, texts transmitted by professional interpreters are as "closed" as any "cultured" text, even if they are 
intended for popular consumption. The prestige of the professional interpreter and of the media that transmits such texts (radio, television, tapes, records, etc.) effectively prevents the appropriation and reinterpretation of the model by the public. Traditional literature, on the other hand, is conceived by its consumers as belonging to them; it is a product of their culture and thus remains open to transformation as changes in the referent require new interpretations.

This "openness" of oral texts constitutes one of the main differences between popular and traditional literatures, a difference that is seldom made evident when popular traditions are considered, since it is not the nature of the texts that is taken into consideration, but merely the fact that the consumers of both these types of artistic products are members of the popular classes.

I have insisted on the non-specialized character of romance singers because it is central to my discussion of variation and adaptation of romance functions and narrative structures. Romance singers have no desire either to entertain their audiences with innovation or to perfect the text they are reproducing; In fact, their main concern is to render the text exactly the way they learned it. And yet, variation is precisely what characterizes oral traditions. In the course of the life of a romance there is a slow but irreversible change that affects not only the superficial levels of organization of the text, the level of the discourse or of the plot, but also the deeper levels, such as the level of the fabula, where the narrative's causality resronds to its referent, the social reality, or even the functional level. ${ }^{4}$

When we compare the different versions of a romance and observe how the same structure or model can be manifested in many varying forms, the relationship between the different levels of organization of the narrative becomes evident. Any variation at a superficial level of the text can affect a deeper level, which in turn can generate change in the more superficial one. The signified generates its signifier or signifiers, but the signifier(s) can, in turn, regenerate the signified each time the sign is interpreted. Given the openness of oral structures, the new signifieds tend to generate new signifiers that express better or more efficiently those regenerated signifieds. ${ }^{5}$

If, as we have observed, innovation does not occur at a conscious level at the moment of the oral production of a romance, we must look into other stages in the process of transmission of 
the text in order to understand the creative processes of oral traditions. I will discuss some of them briefly.

Oral transmission of a text requires its memorization by the receiver, who will in turn become its transmitter. Memory thus plays a central role in oral traditions; the retention/variation process of oral transmission of texts is closely connected with the way the human mind processes information for long-term memorization.

In recent years many psychologists, linguists, and other specialists in the cognitive sciences have shifted their interest from minimal signifying units to connected discourse as the basis for their studies on memory. Their observations on the relationships between discourse structures and thought processes help us to understand particular narrative structures. ${ }^{6}$

\section{Lexical Variation}

Research has demonstrated that soon after input subjects do not normally retain the precise wording of discourse segments unless they concentrate on that wording. ${ }^{7}$ In the case of romances, the poetic mode plays a crucial mnemonic role; wording is central to memorization of the narrative. Whether romances are sung or recited, their expression is just as important as their narrative content. Nevertheless, a comparison between two different versions of a romance, even if its known versions are not very abundant, reveals an important degree of lexical and syntactical variation. ${ }^{8}$ The opening lines of five versions of Belardo $y$ Valdovinos collected from modern oral tradition can serve as an example:

De Ias guerras ven Bernardos de las batallas venia, cien caballos trae delante todos ganados do un día.

(Lugo)

Don Belardo fue a la guerra la cosa que él más quería; cien caballos trai adiestros, todos los ganó en un día.

(Oviedo)
From the wars came Bernardos from the battles he came, a hundred horses he drives before him all won in one day.

Don Belardo went to war the thing he liked best; a hundred horses he leads, he won them all in one day. 


\author{
Bem se passeia Bernardo \\ pela ribeira de Umbria, \\ leva duzentos cavalos, \\ todos ganhou num dia. \\ (Vinhais, Portugal) \\ Alta vai a lua alta \\ com'o sol de mediodía \\ cuando don conde Belardos \\ de la batalla salia; \\ sacó ciento cien caballos \\ todos a rienda perdida. \\ (Orense) \\ Alta, alta va la luna \\ como el sol del mediodía \\ cuando el conde don Belardo \\ de la campaña salía; \\ seis mulas lleva de rienda, \\ todas las ganó en un día.
}

(Zamora)

\author{
Bernardo was riding \\ along the shore of Umbria, \\ he leads two hundred horses, \\ he won them all in one day. \\ High is the moon high \\ like the noonday sun \\ when Count Belardos \\ left the battle; \\ he took away a hundred horses \\ all swiftly running. \\ High, high is the moon \\ like the noonday sun \\ when Count Belardo \\ left the campaign; \\ six mules he leads by the rein, \\ he won them all in one day.
}

\section{Linguistic Competency}

Given the ephemeral nature of an oral text, the receiver must have the competency to decodify the message at the time of its performance; he must be able to anticipate the meaning of each narrative element as well as the relationships between them as they are being expressed orally. Familiarity with the language utilized in the text, that is, familiarity with the paradigmatic meanings of the narrative units that come together in the narrative, is therefore essential to its understanding and memorization.

Most, if not all, of the poetic language of the romancero is formulaic, that is, it is composed of discourse units of varying lengths that convey a unitary meaning. The use of formulaic language in oral traditions and the role this type of language plays in the structuring of oral texts has been studied by specialists not only in the field of literature, but in fields such as folklore, linguistics, and anthropology as well. The specific nature and use of formulas in the romancero has also been the subject of important studies such as R. H. Webber's (1951). I will thus insist on only one point, on the fact that what is essential to the process of transmission of oral narratives is not the ability of the producers/ consumers of oral texts to use formulas in different contexts, but rather their comprehension of the unitary meaning of formulas. ${ }^{9}$

Let us consider the following discourse formulas that appear 
in two romances, Juan Lorenzo and El prisionero:

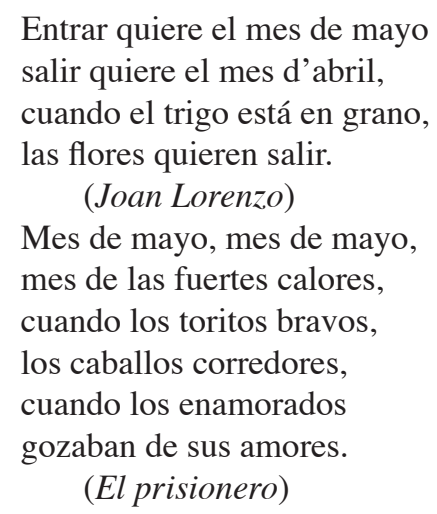

\author{
The month of May is coming in \\ the month of April is going out, \\ when the wheat is ripe, \\ the flowers are coming out. \\ Month of May, month of May, \\ month of severe heat, \\ when the brave bulls, \\ the running horses, \\ when lovers \\ were enjoying their love.
}

Although there are few lexemic and syntactic coincidences between them, they do have an obvious equivalence. The second formula, through a more elaborate description, makes explicit what the first one only insinuated, the surging of sexual plenitude. The arrival of summer with its connotation of sexual plenitude which these formulas express serves in Juan Lorenzo to refer to the protagonist's deprivation of his natural sexual life because another man will take his wife away from him. In the case of El prisionero, the formula is part of the lack of a natural life on the part of the protagonist who, imprisoned, is unable to fulfill his (or her) sexuality. The meaning of the formula is made explicit with the mention of brave bulls ("toritos bravos"), running horses ("caballos corredores") and lovers who were enjoying their love ("enamorados que gozaban de sus amores").

At the next level of semantic organization of the text, where the plot constitutes the signifier of the fabula, narrative motifs, which are also formulaic, are likewise adjusted to the varying needs of communication of the romance singers.

In La muerte ocultada, a young couple is expecting their first child when the husband is mortally wounded. The tradition presents several possibilities for the encounter of the hero with death. In a version from Salamanca, for example, the hero goes hunting and is killed by a lioness:

$\begin{array}{ll}\text { Salía don Bueso } & \begin{array}{l}\text { Don Bueso went out } \\ \text { a cazar un día, }\end{array} \\ \text { la brava leona } & \text { the savage lioness } \\ \text { de morderle había. } & \text { was to bite him. }\end{array}$

In the Moroccan branch of the tradition, he encounters death personified: 


$\begin{array}{cl} & \text { Levantóse Ueso } \\ & \text { lunes de mañana, } \\ & \text { alzara sus armas } \\ & \text { y a la caza iría. } \\ 5 & \text { En un prado verde } \\ & \text { se sentó a almorzar, } \\ & \text { vio venir a Huerco } \\ & \text { las aguas pasar. } \\ & \text { - Así Dios te deje } \\ & \text { con Alda vivire } \\ & \text { que tú ya me dejes } \\ & \text { las aguas bullire. } \\ & \text {-Así Dios me deje } \\ & \text { con Alda folgare, } \\ & \text { que yo no te deje } \\ & \text { las aguas pasare. } \\ & \text { Hirió Ueso a Huerco } \\ & \text { en el calcañale; } \\ \text { hirió Huerco a Ueso } \\ \text { en la voluntade. }\end{array}$

\author{
Ueso arose \\ one Monday morning, \\ he took up his arms \\ and went out hunting. \\ In a green meadow \\ he sat down to lunch, \\ he saw Huerco coming \\ across the waters. \\ "Thus may God let you \\ live with Alda \\ [and] may you now let me \\ stir up the waters." \\ "Thus may God let me \\ take pleasure with Alda, \\ [and] may I not let you \\ cross the waters." \\ Ueso wounded Huerco \\ in his heel; \\ Huerco wounded Ueso \\ in his will.
}

And in the following version from Cáceres, as in the majority of versions collected from modern oral tradition, war is the cause of death:

Estando don Pedro
sentado a la mesa,
le vino la orden
para ir a la guerra.
Ya viene don Pedro
de la guerra herido,
y doña Teresa,
cuanti había parido.

\author{
When Don Pedro was \\ seated at the table, \\ there came to him the order \\ to go to war. \\ Now Don Pedro is returning \\ from the war wounded, \\ and Doña Teresa, \\ who had already given birth.
}

The plot segments, "the hero goes hunting" and "the hero goes to war," are not the same, nor is the battle between Huerco (death personified in Judeo-Spanish) and the hero, who tries to prevent Death from crossing the barrier of water that separates the world of the living from the world of the dead, the same as the hero's being mauled to death by a lioness. The unitary signification of the narrative motif, "the hero is mortally wounded as he encounters death," is reinterpreted in terms of the social environments of the romance singers. As man no longer encounters death in a direct confrontation with other-world forces or with wild beasts, man himself becomes his natural enemy, and he dies in battle against man. ${ }^{10}$

The substitution of discourse or plot formulas for others of equal semantic value demonstrates the capacity of romance singers to understand their unitary meaning. Memorization of formulas 
implies their decodification. Familiarity with the language of the text with the signifying units utilized in the narrative is not only essential to its understanding and memorization, but it also helps in the memorization of other similar texts, other romances.

\section{Semantic Cohesiveness of the Text}

Comprehension and retrieval of memorized information at the time of its rendition requires strong semantic cohesiveness of the text. In order to achieve cohesiveness, all the elements that comprise its discourse must be integrated with one another (see Bransford and MacCarrell 1974). The orally transmitted text can retain global coherence throughout time and space only if the receiver/transmitter can comprehend the causal relationships between the actions and situations presented in the narrative. The capacity of the romance's narrative to adapt semically and lexemically to its changing referent makes possible its continued semantic coherence.

In order to strengthen the semantic coherence of a text, while at the same time helping the receiver to anticipate the signification of the elements that comprise the narrative, romances count on the use of indices (see CGR 1.A, 1984). An index is a narrative element of varying complexity (it can be a single word or a formula comprising several verses) which refers not to what happens in the narrative, but rather to what is. It is not a part of the syntagmatic chain of events. The signification of an index is paradigmatic; it cannot be completed within the syntagma where it appears (see Barthes 1966:1-27). Indices help to understand the actions of characters by pointing to their traits or to the nature of events. Although they are often redundant expressions of the narrative content, they are essential to the understanding of the fabula, where the narrative's causal relationships are established.

The romancero utilizes different types of indices, some of them a part of its particular semantic system, for example, specific occasions when an event might occur, like St. John's Day, the summer solstice, or Monday, signaling something ominous. The listener can anticipate the death of the protagonist when romances include formulas like: "Un lunes por la mañana / don Pedro de caza salía” (One Monday morning, Don Pedro went out hunting) and "Don Diego salió; de caza / un lunes por la mañana" (Don Diego went out hunting one Monday morning). Likewise in La esposa de don García, which begins with "Yo me levantara un 
lunes / un lunes muy de mañana" (I got up one Monday, one Monday very early). Monday presages the ill fortune of the protagonist who is to be kidnapped by the Moors.

Other indices are semantic cliches that belong to a universal mythical tradition, such as the water that separates the world of the living from the world of the dead in La muerte ocultada, or the locus amoenus where encounters occur signaling the amorous nature of the encounter. For example, the maiden going on a pilgrimage or to her brother's wedding in La fatal ocasión will successfully escape her pursuer until they reach a cool fountain, the locus amoenus:

El correr y ella correr, alcanzarla no podía; quiso Dios que la alcanzó al pie de una fuente fría.
He was running and she was running, he could not overtake her; God willed that he should overtake her at the foot of a cool spring.

or:

Mucho corre el caballero, tanto y más corre la niña, se llegaron a encontrar al pie de una fuente fría.
The knight runs hard, the girl runs even harder, they came together at the foot of a cool fountain.

Given the place of the encounter, the lad's intentions become obvious:

- Si viniera a quitarme honra, Dios le quitare la vida.
If you came to take away my honor, may God take away your life.

Other sites such as a green meadow ("en un verde prado") or the shade of an olive tree ("al pie de una verde oliva") are also understood as indices that a love encounter, whether natural or forced, is going to take place.

Indices also play an important part in the romancero in providing coherence in texts where events are not presented in their logical place within the narrative. For example, in Bernal Francés, a romance of adultery, the husband pretends to be his wife's lover in order to test her. As the narrative begins with the arrival of the disguised husband, several indices are used to help the listener understand what is happening before it is made evident: the candlelight which would reveal the identity of the supposed lover is blown out when he enters the room, providing a clue that something is not right. The wife is also called wretched ("la güitada") when she is getting ready to go to the arms of her lover, making the listener aware that tragedy will befall her, thus helping to decodify the seemingly discordant elements of the 
narrative.

\section{Social Competency}

The decoding of information is an active process that requires the invoking of previously acquired information. Comprehension and memory are sensitive to contextual constraints, to the way in which referential, semantic, and pragmatic environments direct the processing of the information that has been received. ${ }^{11}$

Participants in the chain of transmission of oral texts decodify the narratives in terms of their own social structures. The types of relationships they establish between the actions and situations narrated and the world as they perceive it will not only determine their comprehension and memorization of the text, but in addition it will necessarily play a part in their restructuring of the narrative when the information is retrieved in a future oral performance of the text. ${ }^{12}$

Our experience of several years of collecting romances from oral tradition in Spain and Portugal confirms something that has been observed by previous generations of collectors but has not been analyzed in all its consequences: the fact that the majority of our informants, and therefore the principal depositaries of oral traditions, are women. I would also point out that the phenomenon is not limited to the Hispanic romancero. In the works of Latin American authors who utilize materials from oral traditions, we have testimonies that their sources are almost invariably feminine. Such is the case, for example, of Miguel Angel Asturias, Gabriel García Márquez, and José Emilio Pacheco. ${ }^{13}$

A statistical study of Gerineldo, one of the most widespread romances in the modern oral tradition, reveals the following: for the 819 versions published by the Seminario Menéndez Pidal in the Romancero traditional de las lenguas hispánicas, we have the names of 668 informants of whom 549 are women, more than $82 \%$ of the total. Interestingly, many of these women were not old: 277 of them were under fifty years of age, and 42 of them were under twenty (Gerineldo 1975-1976).

Feminine transmission of oral literature is not merely a sociological fact since, given the openness of this type of literature, the active role played by women in the creative processes of oral traditions has necessarily been a determining factor in their function and structure. In several centuries of traditional life, 
women's voices and their world views have been incorporated into these forms inherited from the past.

The romance of Las quejas de doña Urraca, which we know both in its sixteenth-century tradition and in versions collected from modern oral tradition, provides us with an example of how a text that originally offered a political commentary on a historical event, i.e., which had had a more or less journalistic function, has been able to survive by adapting its narrative structure to convey a message relevant to its twentieth-century transmitters. ${ }^{14}$ Las quejas de doña Urraca is an episode taken from the Cantar de la muerte del rey don Fernando, a medieval epic poem which we know only through prose passages that appear in thirteenth and fourteenth-century chronicles: the Primera crónica general, the Crónica de veinte reyes, and the Crónica de 1344.

When Fernando I was on his deathbed, he divided his kingdom among his three sons, Sancho, Alfonso, and García, leaving his daughters, Urraca and Elvira, out of his will. Urraca accuses her father of unjustly disinheriting her and gets him, through threats of dishonoring him, to make a new partition of the kingdom, granting Zamora to her and Toro to Elvira. As he changes his will, the king also demands that his sons take an oath that they will abide by his last will. The partitioning of the kingdom had widespread political repercussions in which the Cid, a partisan of Sancho, the oldest son, was to play an important role. The rivalry between the three brothers resulted in a series of betrayals followed by bloody revenge, which included the well-known hostility between the Cid and Alfonso because of Sancho's murder during the siege of Zamora.

Although the Cid is a hero of almost eternal popularity in most of the Hispanic world, he is not a protagonist of the romance. His role as mediator between father and daughter and his defense of Urraca's rights of inheritance, mentioned by the chronicles and therefore by the Canter de Mio Cid, is not mentioned in the modern romance. The protagonists are King Fernando and Princess Urraca, two historical figures who are not easily recognized by the people who sing the romance in our day. ${ }^{15}$

Both characters, King Fernando I and Princess Urraca, the same as any character appearing in a romance narrative, are defined in terms of their roles as actants in the narrative, in Greimas' terminology: sujet/ objet;destinateur/destinataire; adjuvant/opposant, and as representatives of the narrative's referent, 
the social reality. This double definition is essential to the renovation of a text. Because the relationships between the two characters are defined in terms of the referent, they will be adapted to the new contexts in which the romance is sung.

The romance of Las quejas de doña Urraca as was registered in sixteenth-century cancioneros and broadsides is a brief dialogue between the princess and the king. I will use the version published in the sixteenth-century Cancionero de romances $(1550,1967: 213-14)$ as an example of that tradition:

Morir vos queredes padre san Miguel vos aya el alma mandastes las vuestras tierras a quien se vos antojara a don Sancho a Castilla Castilla la bien nombrada a don Alonso a Leon y a don Garcia a Bizcaya a mi porque soy muger

10 dexays me deseredada yrme yo por essas tierras como vna muger errada y este mi cuerpo daria a quien se me antojara

15 a los Moros por dineros y a los Christians de gracia de lo que ganar pudiere hare bien por la vuestra alma. Alli preguntara el rey,

20 Quien es essa que assi habla? Respondiera el arçobispo Vuestra hija doña Vrraca. Calledes hija calledes no digades tal palabra

25 que muger que tal dezia merescia ser quemada alla en Castilla la vieja vn rincon se me oluidaua çamora auia por nombre çamora la bien cercada de vna parte la cerca el Duero de otra peña tajada del otro la moreria vna cosa muy preciada quien vos la tomare hija la mi maldicion le cayga. Todos dizen amen amen sino don Sancho que calla. El buen rey era muerto
You are about to die father may Saint Michael have your soul you gave away your lands to whomsoever you chose to Don Sancho Castile renowned Castile to Don Alonso León and to Don García Vizcaya because I am a woman you leave me disinherited I shall go through those lands like a sinful woman and give this body of mine to whomsoever I choose to Moors for money and to Christians free what I can earn I will offer for your soul. Then the king asked, Who is it that is speaking this way? The archbishop answered Your daughter Doña Urraca. Be silent daughter be silent don't say such a thing for a woman who said such a thing would deserve to be burned there in old Castile [is] a corner I forgot about Zamora is its name well-encircled Zamora on one side the Duero surrounds it on another a steep cliff on another the Moorish district a very prized thing whoever takes it from you daughter upon him may my curse fall.

All say amen, amen except Don Sancho who is silent. The good king was dead Zamora is now encircled on one side the king surrounds it 
del otro el Cid la cercaua del cabo que el rey la cerca çamora no se da nada 45 50 del cabo que el Cid la cerca

çamora ya se tomaua

Assomose doña Vrraca

assomose a vna ventana de alla de vna torre mocha estas palabras hablaua on the other the Cid surrounded it on the side that the king surrounds Zamora does not yield at all on the side that the Cid surrounds Zamora was already taken Doña Urraca appeared she appeared at a wlndow from there from a flat tower she spoke these words.

The sixteenth-century singers of the romance were perfectly familiar with the obligations and prerogatives of kings and princesses and with the social codes of the nobility omnipresent in the narrative. In that context the protagonist, a princess, could forcefully claim her part of the kingdom by reminding her father that not only male children were the depositaries of the king's honor, but that she, equally an inheritor of his blood, could also jeopardize his honor. In spite of being a woman, she thus had the right to demand the means necessary to maintain that honor.

The threat of prostituting herself used by Doña Urraca as a way of forcing her father to change his will, obviously an exaggerated recourse in the case of a princess, in more current contexts has been interpreted literally. Prostitution, although an extreme measure, constitutes, in fact, one of the few possibilities for a woman without any means whose horizon is limited to prostitution or to the undertaking of lowly tasks: ${ }^{16}$

E eu vou-me por 'qui fora como triste desgraçada, nem de preto, nem de branco de ninguem serei guardada, com a minha roca a cinta, mulher não tem outra arma.
And I'm going out from here as a sad wretched woman, neither by black, nor by white nor by anyone will I be protected, with my distaff girded on, a woman has no other weapon.

As reality changed and the codes that ruled the causality of the tale became obsolete, the narrative had to adjust the causality of the events to the new reality in order to retain its semantic coherence. The drama of a young woman condemned by her father to a life of poverty and dishonor demanded an explanation more in accord with the world view of the romance transmitters, an explanation they found in another narrative that deals with the conflict between a father and a daughter, the romance of Silvana, which tells of such a conflict arising out of her rejection of his incestuous advances.

In the modern Portuguese insular tradition Las quejas de doña Urraca begins with Silvana or with a combination of Silvana 
and Delgadina, another romance with a father-daughter incest theme: ${ }^{17}$

Passeava Dona Silvana por sua corredor acima se ela canta, melhor bailha, melhor romances fazia.
Seu pai andava-a mirand' todas as horas do dia

- Bem podias, Silvana, seres minha pel' um dia -Serei um, e serei duas, do papai sou toda a vida; mas as penas do inferno, papai, quem as passaria? - Sou eu, Dona Silvana, que as passo toda a vida. - Vá, meu pai, para o seu quarto, p'a á sua fresca camilha, que eu von-me para o meu quarto, vestir minha alva camisa. Foi Silvana para o seu quarto, mais triste que a noite o dia; chamava por sua mãe, há sete anos falecida.

-O que queres, minha filha o que queres, filha minha? Empresta-me os teus vestidos, teus fatos de cada dia, que eu quero ir ver teu pai, o ladrão o que te queria Como podes conhecer honra a quem três filhos [pariu)? Um foi Dom Pedro de Castro, outro João de Castilhas, outra foi Dona Silvana, filha que nunca teria. -Oh que vozes são estas que eu oiço tão desmudadas? -E a nossa filha Silvana, chora que 'ta desgraçada.

- A João deixo-lhe as cases, a Pedro terras lavradas. - A nossa filha Silvana, essa não lhe deixas nada? -Lá lhe deixo aquela boia e aquela boia dourada. Pel' uma banda corre ouro, por outra a prata lavrada. -Quando ela nasceu no mundo, já a boia i-era tomada
Dona Silvana was walking along her corridor, if she can sing, she can dance better, [and] make better romances. Her father kept watching her all the hours of the day.

"You could, Silvana, be mine for a day."

"It would be one, and it'd be two, my whole life belongs to my father; but hell's torments, father, who would endure them?" "I am the one, Dona Silvana, who has endured them all my life." "Go, my father, to your room, to your fresh bed,

for I'm going to my room, to put on my white chemise." Silvana went to her room, sadder than night or day; she called for her mother, dead for seven years.

"What do you want, my daughter, what do you want, daughter of mine? Lend me your clothes, your everyday things, for I want to go and see your father, the thief who loves you.

How can you know honor [you] for whom I bore three children? One was Don Pedro de Castro, another João de Castilhas, another was Dona Silvana, a daughter [I wish] I never had."

"Oh what cries are these I hear that are so distraught?" "It is our daughter Silvana, she weeps because she is dishonored."

"To João I leave the houses, to Pedro cultivated lands." "To our daughter Silvana don't you leave anything?" "To her I leave that bola there, that boia of gold.

Along one side runs gold, along another wrought silver." "When she was born into the world, already the boia was taken 
50

55

60

65 entre duques e marqueses, todos de espada dourada.

-Rei que 'tas para morrer, diste tum'a parte n'alma; repartistes os teus bens e a mim não me destes nada. -Lá te deixo aquela boia, e aquela boia dourada, pel' uma banda corre ouro, por outra prata lavrada. -Quando eu nasci neste mundo, já a boia i-era tomada, entre duques e marqueses, todos de espada dourada. Vai Silvana per ali fora como pobre desgraçada, c'a sua roca à cintura, mulher não tem outra arma. by dukes and marquis, all with golden swords." "King who are about to die you gave up my part of your soul; you divided up your possessions and didn't give me anything." 'I leave you that boia there, that boia of gold, along one side runs gold, along another wrought silver." "When I was born into this world, the boia was already taken, by dukes and marquis, all with golden swords." Silvana goes away from there as a poor dishonored woman, with her distaff at her waist, a woman has no other weapon.

The tale of a princess' right to her part in the partition of the Spanish kingdom has become, without losing an important number of historical details, a commentary on woman's dependency and subordination to her father, her powerlessness before his whims, and the limited possibilities she has to provide for herself if she loses her father's support.

The theme of incest, adopted by Las quejas de doña Urraca in order to clarify the antagonism between the protagonists, is the subject of several romances collected from modern oral tradition. ${ }^{18}$ Also with a historical reference we have versions of Las almenas de Toro, dramatized by Lope de Vega in his comedy of the same name. In the latter romance the king's fury because the woman he admires and wants to make either his wife or his mistress, depending on her social rank, turns out to be his sister and he is therefore banned from having her, drives him to have her killed by his men. ${ }^{19}$ Among folkloric romances we have the already mentioned Silvana and Delgadina, and of Biblical inspiration, Tamar, a romance that has been collected in practically every region of Spain as well as among Moroccan Sephardim. The more than two hundred versions of Tamar collected from modern oral tradition offer us a wide range of positions adopted by its transmitters/creators towards this problem of such vital concern to women. Tamar was also registered in the sixteenth century, but that tradition, very close to the Biblical story (2 Sam. 13-14), has little to do with the modern oral tradition ${ }^{20}$

The romance narrates the rape of Tamar (or Altamara) by 
her brother when, at her father's request, she goes to her brother's room where he lies in bed claiming to be sick. Her cries of grief and desperation are heard by her father, whose response to her plight varies from one branch of the tradition to another. One of the few versions in which the father shows a concern for his daughter is from Vich (Catalonia), which bases his reaction on the fact that he is first of all a king and must act as a ruler. ${ }^{21}$ Incest is considered a social crime that must be punished according to the law. The king, after hearing from his daughter what she claims to have occurred, confronts his son with his sister's accusation. When the son accepts his guilt, he condemns him to be burned as an example for all his subjects:

$\begin{array}{ll}\text {-Posa 't en confesion } & \text { "Go to confession, } \\ \text { que promptament ets de cremar-ne; for soon you are to be burned; } \\ \text { que si el rei permetia allo, } & \text { for if the king permitted that, } \\ \text { que farien los vassalls! } & \text { what would the vassals do!" }\end{array}$

More common is the little concern shown by the father towards Tamar's plight after having sent her, his own daughter, to "comfort" his son. In spite of her distress, the father is only interested in his son:

$\begin{array}{ll}\text { - } \text { Cómo queda mi hijo, } & \text { "How is my son, } \\ \text { cómo queda en la cama? } & \text { how is he in bed?" } \\ \text { - El su hijo queda bueno, } & \text { "Your son is well, } \\ \text { pero yo vengo enojada. } & \text { but I am outraged." } \\ \text { - Como mi hijo quede bueno, } & \text { "As long as my son is well, } \\ \text { por tus enojos no hay nada. } & \text { your outrage doesn't matter." } \\ \text { (Zamora, Albacete, Lugo, Portugal, Cuba) }\end{array}$

Not only is the king not concerned with the victim, but the solutions he proposes treat lightly the violence committed against his daughter. In Albacete and Zamora, for example, the father suggests that the whole thing be kept quiet by shutting her up in a convent:
- No llores mi Altamarita,
"Don't cry my Altamarita, no llores mi Altamarada, don't cry my Altamarada, que yo te meteré a monja for I will place you as a nun convento de Santa Clara. [in the] convent of Santa Clara."

In Lugo and Santander he proposes that she quietly marry:

-Calla, calla, el Altamar, de ti no se sepa nada, que en lo que tu padre vive estarás tú bien casada.

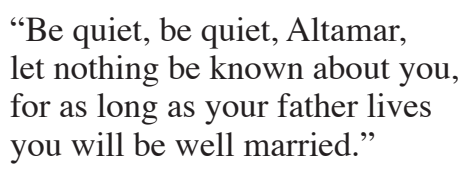

"Be quiet, be quiet, Altamar, let nothing be known about you, for as long as your father lives you will be well married."

Both solutions require that the whole incident be kept secret. But 
a marriage to her own brother, suggested in a version from Lugo, demands more than discretion; it requires the Pope's intervention:
- Cala, Tamariña, cala,
"Be quiet, Tamarina, be quiet, que con él serás casada. for you will be married to him."
- ?Cómo ha de ser eso, mi padre, "How can that be, my father, siendo yo su propia hermana? since I am his own sister?"
- Hay un Padre Santo en Roma que a todos purificaba.
"There is a holy father in Rome who purifies everyone."

Every one of the solutions proposed by the father are acceptable only in social terms; they have little to do with the forced woman's grief, and she rightly rejects them:

- !Vaya un consuelo de padre para buena deshonrada!

or:

- No se me da que me oigan, ni tampoco ser casada, dáseme por la mi alma, no la quería manchada.

\begin{abstract}
"What a consolation from a father
\end{abstract} for a dishonored girl!"

Her father's indifference and his inability to come up with an acceptable solution leave her with the alternative of either appealing to higher forces, God (or the Devil), or to her own. As an example of the first instance, we use a version collected in Havana, Cuba in 1912:

-El su hijo bueno queda !si el demonio lo llevara!Aun la palabra no es dicha ya la casa está rodeada; unos entran por la puerta otros entran por ventanas. -Devuelve tú, la mi hija, devuelve tú la palabra.

10 - Palabra que yo dijese no sería redoblada.

- Ya quedarías a gusto, ya quedarías vengada.

- Aun no he quedado yo a gusto, aun no he de quedar vengada

15 mientras no le vea arder y l'arramble la cernada.
"Your son is well may the devil take him!" The word is not even said the house is already surrounded; some enter by the door others enter by windows. "Take back, my daughter, take back the word."

"The word that I said won't be revoked."

"Now you must be pleased, now you must be avenged."

"I am still not pleased,

I still won't be avenged until I see him burn and cover over his ashes."

The second solution appears in versions from Albacete, León, and Guadalajara:

La niña pidió un puñal The girl asked for a dagger $\mathrm{y}$ en el pecho se lo clava. and stabs it in her breast. 
-Que quiero morir con honra

y no vivir deshonrada.
"I want to die with honor and not live dishonored."

The Andalusian tradition, which is strongly influencing other regional traditions, suggests another type of solution: the birth of a child, a solution which overrides the affront in favor of the woman's natural instinct as a mother:

$\begin{array}{ll}\text { De los siete pa los ocho } & \text { From seven to eight } \\ \text { los pañalitos bordaba, } & \text { she embroidered diapers, } \\ \text { de los ocho pa los nueve } & \text { from eight to nine } \\ \text { las camisinas bordaba } & \text { she embroidered little shirts } \\ \text { con un letrero que dice: } & \text { with a phrase that says: } \\ \text { hijo de hermano y hermana. } & \text { son of brother and sister. }\end{array}$

The growing protagonism of Tamar in the romance, which has left behind the original Biblical tale's concern with Amnon's death at the hands of his avenging brother, Absalom, resulting in the rise of Solomon, Amnon's younger brother, to the throne, has not altered the structure of the fabula although it has altered the message conveyed by the narrative.

The young woman's rejection of any solutions to the rape by her brother that subordinate her to social considerations, reveals, in my opinion, a defiant feminine viewpoint which brings to light the active role of women in the creative process of oral traditions. The women who were transmitting a narrative that deals with the problem of incest could not be indifferent to its solution, and their views on the subject have been incorporated into the romance's narrative structure.

It is dangerous and somewhat contradictory to speak of authorship when dealing with collective poetry, but the multisecular, active participation of women in the process of transmission/re-creation of orally transmitted poetry has necessarily had a determining influence on it. The complete picture of how a prevalently feminine transmission of romances has, in fact, shaped the composition of the genre as well as the development of individual romance narrative structures requires not only a consideration of the total inventory of the themes that are still present in modern oral tradition, but a comparative analysis of all the individual versions of each romance theme as well, a very complex task that would require the effort of many researchers interested in the romancero.

The hundreds of hours of recordings of romances collected from oral tradition in the last ten years have produced, as I havev 
noted, thousands of romance texts which add to the already considerable materials from the unedited collections of the Menéndez Pidal archive and other private collections. Paradoxically, it is the abundance of materials that makes difficult any attempt to undertake a comprehensive study of modern oral tradition. The results, however, should be of interest, in my opinion, not only to romancero specialists, since they could also serve as an example of the behavior of oral traditions in general.

The romances of Las quejas de doña Urraca and Tamar are but two examples of romances whose functions and messages have changed quite radically in the course of their traditional lives. They serve to underline the fact that themes that have been able to adapt themselves in order to convey commentaries on subjects of importance to women have been able to survive while others are disappearing, their social function having expired.

New approaches in romancero studies have brought forth the creative aspect of modern oral tradition. Although there has been a reduction in the number of romances with a historical referent that have been retained by the tradition, there has also been important creativity on the part of romance transmitters as they have adapted forms and themes inherited from the past to their own needs of communication. ${ }^{22}$

The functions and structures of the traditional romancero have changed in the course of several centuries of traditional life. The projection of heroes who exemplified political behavior has been adapted to present more personal or individual modes of behavior. The creativeness of many generations of "common" people has not only kept alive an archaic literary form, but it also continues to produce poetic narratives of great beauty.

\section{El Colegio de México}

Notes

'Eric A. Havelock (1963) explains Plato's seemingly exaggerated rejection of Greek traditional poetry and his attack on the poets in terms of his overall plan for the reform of the educational system within the ideal state proposed in The Republic. It was because of its effectiveness in transmitting values that Plato wanted to banish the oral performance of poetry which, in his mind, was laden with dangerous ideals.

${ }^{2}$ The texts collected during the Seminario Menéndez Pidal field trips are 
at this time being transcribed and edited for publication; the task, however, is monumental and will require some time to complete. As for romances contained in articles and books, Armistead's extensive bibliography (1979a) and its update to 1985, now in press, together with the Bibliography of the Hispanic Ballad in Oral Tradition (1980) include over 2,000 entries.

${ }^{3}$ Havelock (1963:106-67) insists on the fact that traditional Greek poetry was remembered in varying degrees by the whole population and not only by its performers since this is the only guarantee for the stability of an oral tradition. Romances are short narratives and therefore easily remembered by many.

${ }^{4}$ This division into four levels of semantic organization corresponds to Cesare Segre's (1974). Segre's division, however, is considered by him to be only a means of analyzing texts while we believe that the relationship between the different levels is a generative one.

${ }^{5}$ René Thon (1973:85-106) compares signs with biological forms in which the descendant, the signifier, can become the parent, the signified, within the lapse of a generation.

${ }^{6}$ The specialized bibliography on this topic is very abundant, but the collection of articles on the understanding of stories edited by Teun A. van Dijk (1980a), which represents different approaches to this subject, can be of special interest to oral literature specialists.

${ }^{7}$ In spite of the important progress that has been made in understanding thought processes, current scientific theories cannot fully explain how the semantic system of a speakerhearer is used or how it is learned. Cf. Fodor, Bever, and Garret (1974:141-220).

${ }^{8}$ Diego Catalán and Suzanne Petersen undertook a pioneering computer-aided analysis of the large corpus of La condesita, which revealed, among other things, that important variation occurred even in verses that seemed more stable within the tradition. Cf. Petersen (1976a) and Catalán (1976:55-77).

${ }^{9}$ For a discussion of the narrative units of the romancero taking into consideration the different levels of semantic organization of oral texts, see Beatriz Mariscal de Rhett (in press).

${ }^{10}$ The corpus of published and unpublished texts of this romance as well as a study with a semiotic approach has been published by Beatriz Mariscal de Rhett (1984-1985).

${ }^{11}$ Interdisciplinary approaches to cognitive processes are becoming more and more common, as is the case with Tenn van Dijk's work (1980a). Earlier studies like Maurice Halbwach's (1925, re-ed. 1975) dealt with such issues as the relationship between memory and social class and memory and religious groups.

${ }^{12}$ In his discussion of semantic macrostructures, Tenn van Dijk proposes that, since the general and conventional information that speakers use to create the frames needed to understand discourse is historical and therefore culturally variable, the coherence of a text can only be attained within a given context (1980b).

${ }^{13}$ Gabriel García Márquez recounts how One Hundred Years of Solitude took shape when he remembered the way his grandmother would tell him 
stories: "I had to tell the story just like my grandmother told me hers" (1982:80). Miguel Angel Asturias dedicates his Leyendas de Guatemela (1930): "To my grandmother, who told me stories." Likewise in conversations following his lectures at the University of California at San Diego (January 1985), José Emilio Pacheco talked about his grandmother as his source of tales and legends.

${ }^{14}$ This romance was studied by Joanne B. Purcell (1976). The versions of the romance collected by the author from oral tradition in the Azores, as well as the two unpublished versions from the Menéndez Pidal archive, are included in this dissertation.

${ }^{15}$ Apart from a version from Santa Cruz de los Cuérragos, Zamora, collected by Tomás Navarro Tomás, and a fragment collected in Seville by Manuel Manrique de Lara, both in the Archivo Menéndez Pidal, all the known versions from modern oral tradition are Portuguese from Madeira, the Azores, and the Algarve.

${ }^{16}$ Doña Urraca's threat is used by several seventeenth-century authors like Cervantes in the second part of the Quijote (2:ch.5), Quevedo in his Romance XCIV of the Musa IV, and Ruiz de Alarcón in El semejante a sí mismo (III.vi).

${ }^{17}$ The following version is from Sitio de Pontes, Porto Santo in the Madeira Archipelago. It was sung by Juliana d'Oliveira, 41 years of age, and collected by Joanne B. Purcell (1976).

${ }^{18}$ The incestuous marriage between Urraca and Alfonso, which is not mentioned in the Castilian chronicles, is ratified by more than one testimony: a twelfth-century chronicle by Ibn al-Sayrafi and by the Franciscan Juan Gil de Zamora's "De praeconis civitas Numatinae" of 1282. Cf. Lévi-Provençal and Menéndez Pidal (1948:157-66).

${ }^{19}$ Both in the romance and in Lope's play, the incestuous relationship between Doña Urraca and her brother Alfonso is transferred to Doña Elvira and her brother Sancho.

${ }^{20}$ Armistead and Silverman demonstrate (1974:245-59; 1982:96-101) that the romance published in the sixteenth century is not the origin of the romances of modern oral tradition. They propose that the various published romances from that period simply attest to the popularity of the theme in the sixteenth-century romancero tradition.

${ }^{21}$ Marguerite M. Morton studies this conflict between the roles that Tamar's father must play (1979). She proposes that the king in fact has three conflicting roles: the role of king, the role of father, and that of a mother who has to look after a sick son.

${ }^{22}$ Paul Bénichou (1968a) challenged Ramón Menéndez Pidal's theory of an "aedic" or creative period in the romancero tradition, the fifteenth and sixteenth centuries, followed by a "rhapsodic" period or age of decadence in which there has been little creativity, roughly since the beginning of the seventeenth century. Menéndez Pidal's theory, however, was directly related to his interest in romances with Spanish historical themes at the time he wrote his important series of essays, "Poesta popular y romancero" (1914-16; 1973), in which he set forth that theory. 